\title{
KARAKTERISTIK MARSHALL QUOTIENT PADA HOT MIX ASPHALT MENGGUNAKAN AGREGAT ALAM SUNGAI OPAK
}

\author{
Maris Setyo Nugroho ${ }^{1}$ \\ ${ }^{1}$ Pendidikan Teknik Sipil dan Perencanaan, Fakultas Teknik, Universitas Negeri Yogyakarta \\ Email: marissetyo@uny.ac.id
}

\begin{abstract}
The purpose of this study is to determine the Marshall Quotient (MQ) value of hot mix asphalt (HMA), which uses natural aggregates from the Opak river. In addition to the $M Q$ value in this study also examines the value of stability and flow in concrete asphalt mixtures with asphalt content of $6.5 \%$. The research method used was an experimental method in the JPTSP FT UNY road construction laboratory. The testing standard used refers to the Indonesian National Standard (SNI). In addition to testing Marshall values, preliminary testing is also carried out to determine the quality of the material used. Material testing includes aggregate quality testing and asphalt quality testing. Based on the test results, the stability, flow and $M Q$ values were $1177.01 \mathrm{~kg}, 3.20 \mathrm{~mm}$ and $384.05 \mathrm{~kg} / \mathrm{mm}$ respectively. When compared with the requirements in the RSNI 03-1737-1989, only the flow values do not meet the requirements.
\end{abstract}

Keywords: hot mix asphalt (HMA), stability, flow, marshall quotient

\begin{abstract}
ABSTRAK
Penelitian ini bertujuan untuk mengetahui nilai Marshall/Marshall Quotient (MQ)dari campuran aspal panas/hot mix asphalt (HMA), yang menggunakan agregat alami dari kali Opak. Selain nilai MQ pada penelitian ini juga mengkaji nilai stabilitas dan kelelehan (flow) pada campuran aspal beton dengan kadar aspal $6,5 \%$. Metode penelitian yang digunakan yaitu metode eksperimental di laboratorium konstruksi jalan JPTSP FT UNY. Standar pengujian yang digunakan mengacu Standar Nasional Indonesia (SNI). Selain pengujian nilai Marshall juga dilakukan pengujian pendahuluan untuk mengetahui mutu material yang digunakan. Pengujian material yang dilakukan meliputi pengujian mutu agregat dan pengujian mutu aspal yang digunakan untuk campuran aspal beton. Bersarkan hasil pengujian diperoleh nilai stabilitas, kelelehan, dan nilai Marshall berturut-turut sebesar $1171,01 \mathrm{~kg}, 3,20 \mathrm{~mm}$, dan $384,05 \mathrm{~kg} / \mathrm{mm}$. Jika dibandingkan dengan persyaratan nilai stabilitas, kelelehan, dan nilai marshal yang tercantum pada RSNI 03-1737-1989, hanya nilai kelehan saja yang tidak memenuhi persyaratan.
\end{abstract}

Kata kunci: hot mix asphalt (HMA), stabilitas, kelelehan, nilai marshall 


\section{PENDAHULUAN}

Infrastruktur jalan memegang peranan penting dalam kehidupan masyarakat. Di Indonesia, konstruksi jalan sudah banyak berkembang, salah satunya menggunakan campuran aspal beton, karena dalam campuran ini akan menghasilkan lapisan perkerasan yang kedap air dan tahan lama, dengan harga yang relatif lebih murah dibandingkan dengan kontruksi jalan tipe yang lain. Jenis konstruksi jalan yang menggunakan campuran aspal beton, umumnya digunakan pada jalan dengan beban lalu lintas yang tinggi.

Agregat dan aspal merupakan bahan utama dalam campuran aspal beton. Pada proses pelaksanaanya kebutuhan agregat sering disuplai dari wilayah terdekat dari lokasi proyek konstruksi jalan. Di Yogyakarta sendiri dikenal sebagai daerah yang memiliki sumber daya alam yang melimpah, sala satunya yaitu agregat. Agregat yang ada di Yogyakarta berasal dari hasil erupsi gunung Merapi yang terbawa arus anakanak sungai yang ada dilereng gunung Merapi. Salah satu anak sungai yang berdada di lereng gunung Merapi yaitu sungai Opak. Disepanjang bantaran sungai Opak banyak terdapat penambangan agregat alam yang membuat stok agregat yang sangat melimpah. Melimpahnya agregat alam yang ada di bantaran suangai Opak perlu ditingkatkan kebermanfaatnnya, salah satunya digunakan sebagai bahan campuran aspal beton.

Berdasarkan latar belakang permasalahan diatas peneliti tegerak untuk mengetahui karakteristik campuran aspal beton dengan memamnfaatkan material dari sungai opak sebagai agregat dalam campuran.

Tujuan dari penelitian ini untuk mengkaji stabilitas, kelelehan (flow), dan nilai Marshall Quotient (MQ) dari campuran aspal beton yang menggunakan agregat dari sungai Opak. Jenis aspal yang digunakan merupakan aspal Pertamina Pen $60 / 70$ dengan kadar aspal dalam campuran sebesar $6,5 \%$.

\section{Campuran Aspal Beton}

Campuran beraspal panas terdiri dari kombinasi agregat yang dicampur dengan aspal. Pencampuran dilakukan sedemikian rupa sehingga permukaan agregat terselimuti aspal dengan seragam. Untuk mengeringkan agregat dan memperoreh kekentalan aspal yang mencukupi dalam mencampur dan megerjakannya, maka kedua-duanya dipanaskan masing-masing pada temperatur tertentu, (Pedoman Pelaksanaan Lapis Campuran Beraspal Panas:2007).

Jenis campuran beraspal dibedakan menjadi:

a. Latasir (lapis tipis aspal pasir/sand sheet), yaitu lapis penutup permukaan jalan yang terdiri atas agregat halus atau pasir atau campuran keduanya dan aspal keras yang dicampur, dihampar dan dipadatkan dalam keadaan panas pada temperatur tertentu.

b. Lataston (lapis tipis aspal beton/HRS), yaitu lapis permukaan yang terdiri atas lapis aus (lataston lapis aus/HRS-WC) dan lapis permukaan antara (lataston lapis permukaan antara/HRS-Binder) yang terbuat dari agregat bergradasi sejang dengan dominasi pasir dan aspal keras yang dicampur, dihampar dan dipadatkan dalam keadaan panas pada temperatur tertentu.

c. Laston (lapisan aspal beton/AC), yaitu lapis permuakaan atau lapis fondasi yang terdiri atas lapis aus (AC-WC), laton lapis permukaan antara (AC-BC) dan laston lapis fondasi (AC-Base). Setiap 
jenis campuran AC yang menggunakan bahan aspal polimer atau aspal dimodifkasi dengan Asbuton atau aspal multigrade atau aspal keras Pen 60 dengan Asbuton butir disebut masingmasing sebagai AC-WC modified, ACBC modified, dan AC-Base Modified.

Menurut Sukirman (2007), Aspal beton adalah jenis perkerasan jalan yang terdiri dari campuran agregat dan aspal, dengan atau tanpa bahan tambahan. Materialmaterial pembentuk aspal beton dicampur di instalasi pencampur pada suhu tertentu, kemudian diangkut kelokasi, dihamparkan, dan dipadatkan. Suhu pencampuran ditentukan berdasarkan jenis aspal yang akan digunakan. Jika digunakan semen aspal, maka suhu pencampuran umumnya antara $145^{\circ}-155^{\circ} \mathrm{C}$, sehingga disebut aspal beton campuran panas. Campuran ini dikenal dengan nama "hot mix". Aspal beton yang menggunakan aspal cair dapat dicampur pada suhu ruang, sehingga dinamakan "cold mix". Tujuh karakteristik campuran yang harus dimiliki oleh aspal beton adalah sebagai berikut:

a. Stabilitas, adalah kemampuan perkerasan jalan menerima beban lalulintas tanpa terjadi perubahan bentuk tetap seperti gelombang lalulintas tanpa terjadi perubahan bentuk tetap seperti gelombang, alur, dan bleeding.

b. Keawetan atau durabilitas, adalah kemampuan aspal beton menerima repetisi beban lalulintas seperti berat kendaraan dan permukaan jalan, serta menahan keausan akibat pengaruh cuaca dan iklim, seperti udara, air atau perubahan temperatur.

c. Kelenturan atau flexibilitas, adalah kemampuan aspal beton untuk menyesuaikan diri akibat penurunan (konsolidasi/ settlement) dan pergerakan dari pondasi atau tanah dasar, tanpa terjadi retak. d. Ketahanan terhadap kelelehan (fatique resistance), adalah kemampuan aspal beton menerima lendutan berlubang akibat repetisi beban, tanpa terjadinya kelelehan berupa alur dan retak.

e. Kekesatan/tahan geser (skid resistance), adalah kemampuan permukaan aspal beton terutama pada kondisi basah, memberikan gaya gesek pada roda kendaraan sehingga kendaraan tidak tergelincir ataupun slip.

f. Kedap air (impremeabilitas), adalah kemampuan aspal beton untuk tidak dapat dimasuki air ataupun udara kedalam lapisan aspal beton.

g. Mudah dilaksanakan (workability), adalah kemampuan campuran aspal beton untuk mudah dihamparkan dan dipadatkan.

Hasil bagi Marshall/ Marshall Quotient (MQ) merupakan hasil pembagian dari stabilitas dengan kelelehan. Sifat Marshall tersebut dapat dihitung dengan menggunakan rumus berikut:

$$
M Q=\frac{M s}{M f}
$$

(1)

Keterangan:

MQ : Marshall Quotient, $(\mathrm{kg} / \mathrm{mm})$

MS : Marshall Stability, $(\mathrm{kg})$

MF : Flow Marshall, (mm)

Penelitian yang dilakukan oleh Aqif, (2012), mengenai optimasi kadar aspal beton AC 60/70 terhadap karakteristik Marshall pada lalu linas berat menggunakan material lokal bantak menunjukkan bahwa kadar aspal optimum untuk digunakan sebagai campuran aspal beton dengan menggunakan AC 60/70 dan agregat Bantak adalah kadar aspal 6,5\%. Nilai stabilitas, kelehan dan $\mathrm{MQ}$ dari hasil penelitian tersebut berturut-turut sebesar $1156,44 \mathrm{~kg}, 3,07 \mathrm{~mm}$, dan $377,28 \mathrm{~kg} / \mathrm{mm}$. 


\section{METODE}

Metode yang digunakan dalam penelitian ini adalah metode eksperimen. Benda uji yang dibuat pada penelitian ini adalah campuran aspal beton dengan kadar aspal 6,5\% dari berat total agregat. Metode pengujian benda uji menggunakan metode Marshall untuk mendapatkan nilai stabilitas dan kelelehan (flow) sehingga diperoleh nilai Marshall kuosien. Penelitian dilakukan di Laboratorium Konstruksi Jalan, Jurusan Pendidikan Teknik Sipil dan Perencanaan FT UNY. Standar pembuatan benda uji dan standar pengujian campuran beraspal mengacu pada SNI dan Pedoman Pelaksanaan Lapis Campuran Beraspal Panas. Standar pengujian dan persyaratan aspal yang disajikan pada Tabel 1, sedangkan standar pengujian dan persyaratan agregat disajikan pada Tabel 2. Tujuan pemeriksaan bahan ini adalah diharapkan salah satu faktor kestabilan konstruksi perkerasan dapat terpenuhi, disamping hal lainnya yang berkaitan dengan pelaksanaan dilapangan.

Tabel 1. Standar Pengujian dan Persyaratan Material Campuran Aspal Beton

\begin{tabular}{|c|c|c|c|}
\hline No. & $\begin{array}{l}\text { Jenis Pengujian } \\
\end{array}$ & Metode & Persyaratan \\
\hline 1 & Penetrasi, $25^{\circ} \mathrm{C} ; 100 \mathrm{gr} ; 5$ detik; $0,1 \mathrm{~mm}$ & SNI-2432-2011 & $60-79$ \\
\hline 2 & Titik lembek, ${ }^{\circ} \mathrm{C}$ & SNI 06-2434-1991 & $48-58$ \\
\hline 3 & Titik nyala, ${ }^{\circ} \mathrm{C}$ & SNI-2433-2011 & Min.200 \\
\hline 4 & Daktilitas $25^{\circ} \mathrm{C}, \mathrm{cm}$ & SNI-2432-2011 & Min.100 \\
\hline 5 & Berat jenis & SNI 06-2441-1991 & Min. 1,0 \\
\hline 6 & Kelarutan dalam trichor ethylen, \% berat & RSNI M-04-2004 & Min.99 \\
\hline 7 & Penurunan berat (dengan TFOT), \% berat & SNI 06-2440-1991 & Mak.0,8 \\
\hline 8 & Penetrasi setelah penurunan berat, $\%$ asli & SNI-2432-2011 & Min.54 \\
\hline 9 & $\begin{array}{l}\text { Daktilitas setelah penurunan berat, \% asli } \\
\text { Uji noda aspal }\end{array}$ & SNI-2432-2011 & Min.50 \\
\hline 10 & $\begin{array}{ll}\text { - } & \text { Standar naptha } \\
\text { - } & \text { Naptha xylene } \\
\text { - } & \text { Hephatene xylene }\end{array}$ & SNI 03-6885-2002 & Negatif \\
\hline
\end{tabular}

Sumber: Pedoman Pelaksanaan Lapis Campuran Beraspal Panas,2007

Tabel 2. Standar Pengujian dan Persyaratan Agregat

\begin{tabular}{|c|c|c|c|c|c|}
\hline \multirow{2}{*}{ No. } & \multirow{2}{*}{ Karakteristik } & \multirow{2}{*}{ Standar Pengujian } & \multirow{2}{*}{ Satuan } & \multicolumn{2}{|c|}{ Spesifikasi } \\
\hline & & & & Min. & Maks. \\
\hline 1 & Analisa saringan & SNI 03-1968-1990 & - & & \\
\hline 2 & Berat jenis & SNI 03-1969-1990 & $\mathrm{gr} / \mathrm{cc}$ & 2,5 & - \\
\hline 3 & Penyerapan air & SNI 03-1969-1990 & $\%$ & - & 3 \\
\hline 4 & Kadar air & SNI 03-1971-1990 & $\%$ & - & - \\
\hline 5 & Keausan agregat (abrasi) & SNI 03-2417-1991 & $\%$ & - & 40 \\
\hline
\end{tabular}

\section{HASIL DAN PEMBAHASAN}

Bahan yang digunakan untuk campuran Aspal beton pada penelitian ini terdiri dari aspal Pen 60/70 dan Agregat. Untuk mengetahui kualitas bahan yang digunakan dalam campuran aspal beton maka dilakukan beberapa pengujian dengan hasil sebagai berikut:

\section{Pengujian Aspal}

Bahan yang digunakan untuk campuran aspal beton pada penelitian ini terdiri dari aspal Pen 60/70, agregat kasar, agregat halus dan filler dan aspal. Dari hasil pengujian yang dilakukan terhadap aspal AC 60/70 yang ditunjukkan pada Tabel 3 , 
menunjukkan bahwa kualitas aspal yang digunakan memenuhi spesifikasi yang telah di persyaratkan di dalam Pedoman Pelaksanaan Lapis Campuran Beraspal Panas (2007) dan RSNI 03-1737:1989.

Tabel 3. Hasil Pengujian Aspal Pen 60/70

\begin{tabular}{lccl}
\hline $\begin{array}{c}\text { Jenis } \\
\text { Pemeriksaan }\end{array}$ & Spesifikasi & $\begin{array}{c}\text { Hasil } \\
\text { Pengujian }\end{array}$ & Satuan \\
\hline Penetrasi 25으 & $60-79$ & 69,07 & $0.1 \mathrm{~mm}$ \\
Titik Lembek & $48-58$ & 53 & $\stackrel{\circ}{ } \mathrm{C}$ \\
Titik Nyala & $\geq 200$ & 321 & $\stackrel{\circ}{\mathrm{C}}$ \\
Titik Bakar & - & 323,67 & $\stackrel{\circ}{\mathrm{C}}$ \\
Berat Jenis Aspal & $\geq 1$ & 1,256 & $\mathrm{gr} / \mathrm{cc}$ \\
\hline
\end{tabular}

\section{Pengujian Agregat}

Agregat merupakan salah satu bahan penyusun campuran aspal beton, kualitas agregat sangat mempengaruhi karakteristik campuran aspal beton. Hasil pengujian terhadap agregat kasar, agregat halus dan filler berdasarkan spesifikasi revisi SNI 031737-1989 dapat dilihat pada Tabel 3. Didapatkan nilai keausan agregat alami sebesar $41,88 \%$, hal ini menunjukkan agregat yang berasal dari Sungai Opak tidak memenuhi spesifikasi minimum nilai keausan untuk bahan penyusun Aspal beton yaitu $<40 \%$. Nilai keausan agregat yang berasal dari Sungai Opak yang cukup tinggi inii diindikasikan karena agregat tersebut merupakan hasil pembentukan batuan baru dari erupsi Gunung Merapi di Tahun 2010. Bautan baru ini memiliki porositas yang tinggi hal ini ditunjukkan dari hasil pengujian penyerapan air didapatkan nilai absorsi sebesar $5,69 \%$ nilai ini lebih besar dibandingkan nilai absorsi minimum untuk agregat bahan campuran aspal beton yaitu $<3 \%$. Dengan adanya nilai porositas yang besar mengakibatkan kepadatan pada agregat yang rendah sehingga berat jenis agregat juga rendah. Hasil pengujian berat jenis agregat kasar didapatkan sebesar 2,46 $\mathrm{gr} / \mathrm{cc}$, sedangkan persyaratan berat jenis agregat kasar untuk campuran aspal beton harus $>2,5 \mathrm{gr} / \mathrm{cc}$.
Tabel 4. Hasil Pengujian Agregat Sungai Opak

\begin{tabular}{|c|c|c|c|c|}
\hline \multirow{2}{*}{$\begin{array}{c}\text { Jenis } \\
\text { Pemeriksaan }\end{array}$} & \multirow{2}{*}{ Sat. } & \multicolumn{2}{|c|}{ Persyaratan } & \multirow{2}{*}{$\begin{array}{c}\text { Hasil } \\
\text { Pengujian }\end{array}$} \\
\hline & & Min. & Mak. & \\
\hline Keausan/Abrasi & $\%$ & - & 40 & 41,88 \\
\hline $\begin{array}{l}\text { Berat Jenis } \\
\text { Agreqat Kasar }\end{array}$ & $\mathrm{gr} / \mathrm{cc}$ & 2,5 & - & 2,46 \\
\hline $\begin{array}{l}\text { Penyerapan } \\
\text { air/absorbsi }\end{array}$ & $\%$ & - & 3 & 5,69 \\
\hline Berat Jenis Filler & $\mathrm{gr} / \mathrm{cc}$ & 2,5 & - & 2,58 \\
\hline $\begin{array}{l}\text { Berat Jenis } \\
\text { Agregat Halus }\end{array}$ & $\mathrm{gr} / \mathrm{cc}$ & 2,5 & - & 2,73 \\
\hline
\end{tabular}

\section{Pengujian Campuran Aspal Beton}

Pengujian campuran aspal beton campuran panas untuk mengetahui karakteristik Marshall dari campuran yang meliputi kepadatan (density), berat jenis maksimum campuran, rongga dalam campuran (VIM), rongga terisi aspal (VFA), rongga diantara mineral agregat (VMA), stabilitas (stability), pelelehan (flow) dan Marshall Quotient (MQ) seperti yang disyaratkan dalam RSNI M-062004 difokuskan hanya pada 3 nilai karakeristik Marshall yaitu nilai stabilitas (stability), kelelehan (flow) dan Marshall Quotient (MQ).

Stabilitas campuran dalam pengujian marshall ditunjukan dengan pembacaan nilai stabilitas pada alat uji Marshall yang dikoreksi dengan angka tebal benda uji. Berdasarkan RSNI M-01-2003, stabilitas campuran beraspal yaitu beban maksimum yang dapat diterima suatu benda uji campuran beraspal sampai saat terjadi keruntuhan. Stabilitas merupakan kemampuan lapis perkerasan untuk menahan deformasi akibat beban lalu lintas yang bekerja di atasnya, tanpa mengalami perubahan bentuk seperti gelombang dan alur.

Nilai stabilitas dipengaruhi oleh gesekan antar butiran agregat (internal friction), penguncian antar butir agregat (interlooking) dan daya ikat yang baik dari lapisan aspal (kohesi), disamping itu proses pemadatan, mutu agregat, dan kadar aspal juga berpengaruh. Nilai stabilitas yang 
sudah dikoreksi dengan angka tebal benda uji disajikan pada Gambar 1.

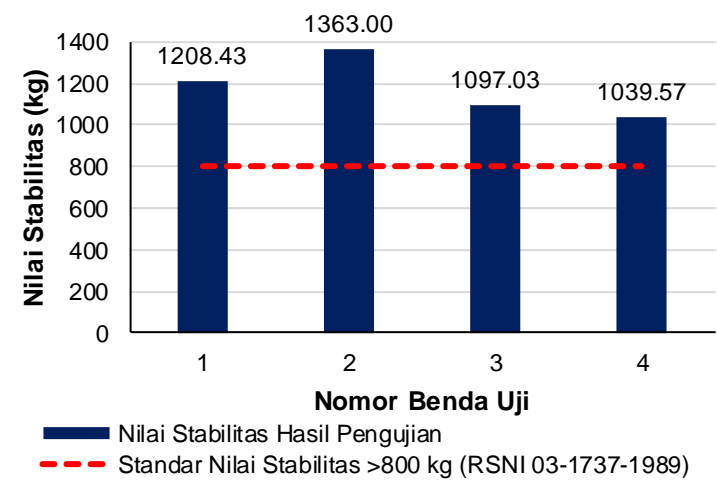

Gambar 1. Nilai Stabilitas

Berdasarkan RSNI 03-1737-1989 dan Pedoman Pelaksanaan Lapis Campuran Beraspal (2007), mengenai ketentuan sifatsifat campuran laston nilai stabilitas minimun untuk lapis perkerasan WC (wearing course) dan BC (base course) yaitu $>800 \mathrm{~kg}$, Berdasarkan hasil rerata nilai stabilitas dan flow yang ditunjukkan pada Gambar 2. Dengan nilai stabilitas rerata campuran sebesar $1177,01 \mathrm{~kg}$, jika ditinjau dari nilai stabilitasnya campuran aspal beton dari agregat kasar sungai opak memenuhi spesifikasi.

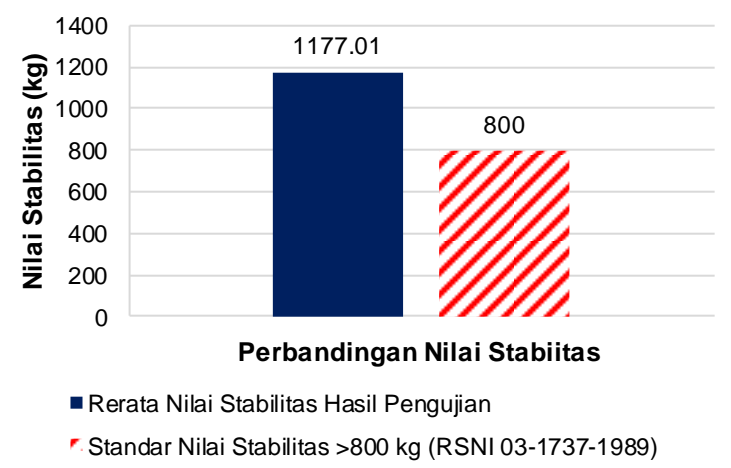

Gambar 2. Perbandingan Rerata Nilai Stabilitas dengan RSNI 03-1737:1989

Flow atau kelelehan merupakan besarnya penurunan atau deformasi yang terjadi pada lapis aspal beton akibat menahan beban yang bekerja diatasnya. Nilai flow akan mempengaruhi fleksibilitas campuran. Nilai flow yang tinggi dan stabilitas rendah menunjukkan fleksibilitas campuran yang tinggi, jika nilai flow rendah dan nilai stabilitas tinggi menunjukkan campuran yang kaku sdan getas (brittle), sedangkan campuran yang memmiliki nilai flow yang tinggi dengan stabilitas rendah akan memiliki sifat plastis yang mengakibatkan campuran mudah berubah bentuk apabila menerima beban.

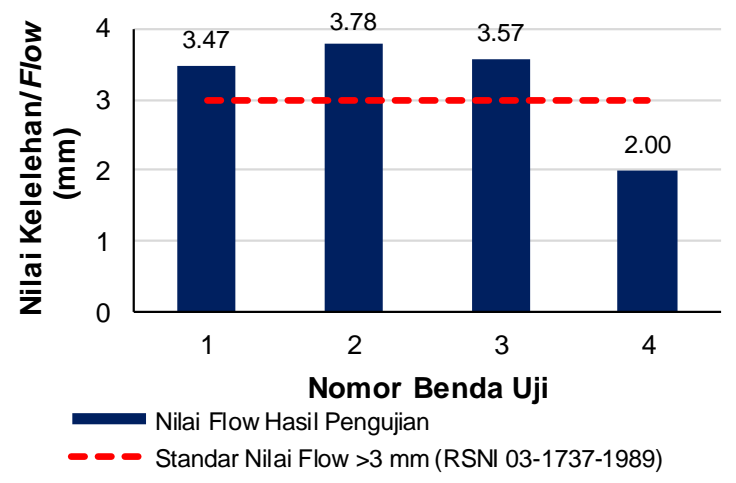

Gambar 3. Nilai Flow

Hasil pengujian nilai kelelehan (flow) pada Gambar 3 menunjukkan bahwa specimen nomor empat yang miliki nilai flow terendah jika dibandingkan dengan specimen yang lain. Jika dikomparasikan dengan nilai stabilitas pada specimen nomor empat $(1039,57 \mathrm{~kg})$ menunjukkan bahwa campuran masih memiliki fleksibilitas yang tinggi. Beberapa faktor yang mempengaruhi nilai flow yaitu gradasi agregat, tekstur agregat, jenis dan kualitas aspal, kadar aspal, proses pemadatan yang meliputi suhu pencampuran, suhu pemadatan serta beban dan jumlah tumbukan pemadatan.

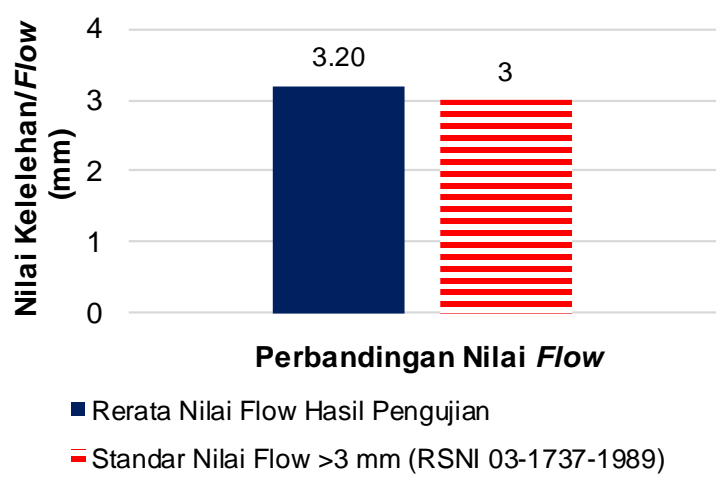

Gambar 4. Perbandingan Rerata Nilai Flow dengan RSNI 03-1737:1989 
Hasil rerata nilai flow sebesar $3.2 \mathrm{~mm}$, jika ditinjau dari rerata nilai flow maka campuran aspal beton memenuhi spesifikasi campuran yang tercantum pada RSNI 031737-1989 dan Pedoman Pelaksanaan Lapis Campuran Beraspal Panas (2007) tentang ketentuan sifat-sifat campuran Laston nilai flow $>3 \mathrm{~mm}$.

\section{Marshall Quotient (MQ)}

Nilai Marshall Quotient (MQ) merupakan hasil bagi antara stabilitas dengan kelelahan (flow) dan merupakan pendekatan terhadap tingkat kekakuan dan fleksibilitas campuran. Semakin besar nilai Marshall Quotient (MQ) berarti campuran semakin kaku dan sebaliknya semakin kecil Marshall Quotient (MQ) maka perkerasanya semakin lentur. Namun nilai $\mathrm{MQ}$ harus dibatasi agar campuran aspal beton memiliki nilai fleksibilitas dan durabilitas sesuai dengan kebutuhan beban lalu lintas.

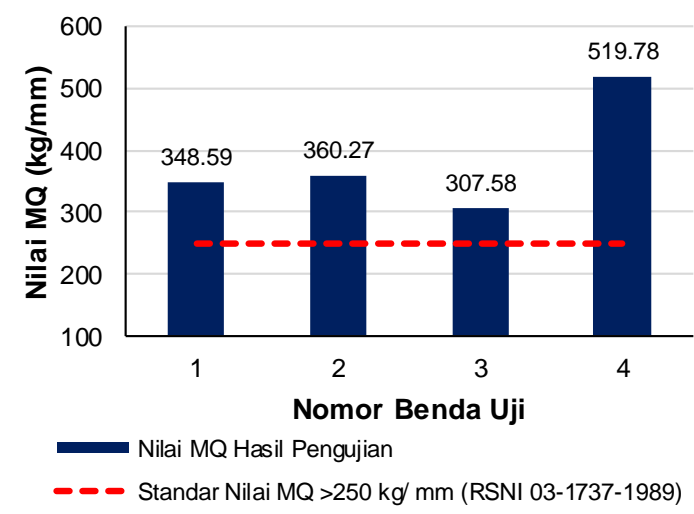

Gambar 5. Nilai Marshall Quotient (MQ)

Nilai Marshall Qoutient (MQ) dinyatakan dalam satuan $\mathrm{kg} / \mathrm{mm}$. Berdasarkan hasil analisis data nilai $\mathrm{MQ}$ dari empat buah specimen (Gambar 5) semuanya memenuhi spesifikasi yang ada dalam RSNI 03-17371989 dan Pedoman Pelaksanaan Lapis Campuran Beraspal Panas (2007) tentang ketentuan sifat-sifat campuran Laston nilai $M Q>250 \mathrm{~kg} / \mathrm{mm}$. Nilai $M Q$ tertinggi pada specimen nomor empat $(519,78 \mathrm{~kg} / \mathrm{mm})$, disebabkan karena nilai flow pada specimen tersebut yang paling rendah sehingga factor pembagi menjadi kecil. Nilai $M Q$ yang tinggi menunjukkan bahwa campuran sangat kaku dan getas.

Berdasarkan dari rerata nilai MQ (Gambar 6) sebesar $384,05 \mathrm{~kg} / \mathrm{mm}$ menunjukkan bahwa campuran aspal beton dari agregat sungai opak memenuhi spesifikasi yang ada dalam RSNI 03-1737-1989 dan Pedoman Pelaksanaan Lapis Campuran Beraspal Panas (2007) tentang ketentuan sifat-sifat campuran Laston nilai $M Q>250 \mathrm{~kg} / \mathrm{mm}$.

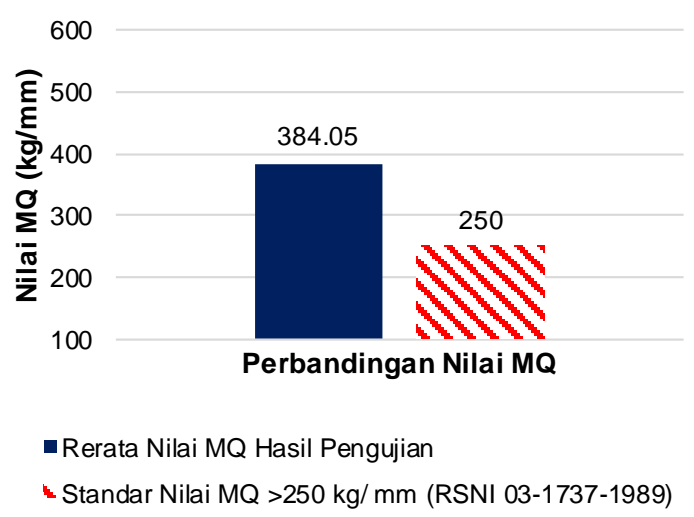

Gambar 6. Perbandingan Nilai MQ

Berdasarkan hasil pengujian stabilitas, flow dan $M Q$, terhadap campuran aspal beton yang menggunakan agregat sungai opak. Dari nilai-nilai hasil uji yang dibandingkan dengan standar dan pedoman yang berlaku menunjukkan bahwa agregat sungai opak yang tidak memenuhi persyaratan keausasn dan berat jenis setelah dilakukan pencampuran dengan aspal, ternyata didapatkan campuran aspal yang memenuhi spesifikasi yang ada dalam RSNI 03-1737-1989 dan Pedoman Pelaksanaan Lapis Campuran Beraspal Panas (2007) tentang ketentuan sifat-sifat campuran Laston yang ditinjau dari nilai Stabililitas, Flow, dan MQ (Tabel 4). Agregat yang tidak memenuhi pesyaratan keusan, absorsi dan berat jenis, ternyata setalah terbalut dengan aspal dapat meningkatkan kualitasnya didalam campuran. 
Tabel 5. Karakteristik Marshall

\begin{tabular}{|c|c|c|c|c|}
\hline \multirow{2}{*}{ Karakteristik Marshall } & \multicolumn{3}{|c|}{ Spesifikasi } & \multirow{2}{*}{ Rerata Hasil Uj } \\
\hline & & WC & BC & \\
\hline \multirow{2}{*}{ Stabilitas, $\mathrm{Kg}$} & Min & & & \multirow{2}{*}{1177.01} \\
\hline & Mak & & & \\
\hline Kelelehan (f/ow), mm & Min & \multicolumn{2}{|c|}{3} & 3.20 \\
\hline Marshall Quotient (MQ),Kg/mm & Min & \multicolumn{2}{|c|}{250} & 384.05 \\
\hline
\end{tabular}

\section{SIMPULAN}

Berdasarkan hasil pengujian dan pembahasan dari campuran aspal beton yang menggunakan bahan agregat sungai Opak dapat disimpulkan bahwa:

1. Nilai stabilitas campuran sebesar $1177,01 \mathrm{~kg}$ memenuhi spesifikasi yang tercantum dalam RSNI 03-1737-1989 dan Pedoman Pelaksanaan Lapis Campuran Beraspal (2007), mengenai ketentuan sifat-sifat campuran laston nilai stabilitas minimun untuk lapis perkerasan WC (wearing course) dan BC (base course) yaitu $>800 \mathrm{~kg}$

2. Jlka ditinjau dari rerata nilai flow maka campuran aspal beton memenuhi spesifikasi campuran yang tercantum

\section{DAFTAR RUJUKAN}

Aqif Muhammad, 2012, Optimasi Kadar Aspal Beton AC 60/70 Terhadap Karakteristik Marshall Pada Lalu Lintas Berat Menggunakan Meterial Lokal Bantak. Yogyakarta: Proyek Akhir, Program Studi Teknik, Universitas Negeri Yogyakarta.

Peraturan Menteri Pekerjaan Umum, 2007, Pedoman Pelaksanaan Lapis Campuran Beraspal Panas.

RSNI 03-1737-1989. Pedoman Tentang "Pelaksanaan lapis campuran beraspal panas" adalah pengganti dari SNI 03-1737-1989, Tata cara pelaksanaan laapis aspal beton (LASTON) untuk jalan raya: Badan Litbang Departemen Pekerjaan Umum.
RSNI M-06-2004. Cara Uji Campuran Beraspal Panas Untuk Ukuran Agregat Maksimum Dari 25,4mm (1 Inci) Sampai Dengan 38mm (1,5 Inci) Dengan Alat Marshall. Badan Standarisasi Nasional.

Sukirman Silvia, 2007. Beton Aspal Campuran Panas. Edisi 2, Penerbit Granit,Jakarta. 